\title{
IMPACT OF THE COVID-19 PANDEMIC ON THE LABOR MARKET IN THE SLOVAK REPUBLIC: WOMEN VS. MEN
}

\author{
JAKUB HARMAN ${ }^{1}$
}

\section{Dopad pandémie COVID-19 na trh práce v Slovenskej republike: Ženy vs. muži}

\begin{abstract}
In the spring of 2020, the world was hit by the COVID-19 pandemic, which had a significant impact on both the economic and noneconomic spheres of everyone's life. The paper deals with the impact of the pandemic on the labour market in the Slovak Republic. The analysis examines data of selected indicators at the level of districts and regions. The results showed a more negative impact on men than on women. The economic activity rate of men decreased on average by 1 p.p., while that of women only by 0.5. At the same time, labor markets in eastern and central Slovakia were affected more than those in western Slovakia. The results of the analysis indicate that people with higher education are more resilient to the corona crisis than those with no or low education, specially women with higher education are more resilient to the corona crisis. A paradoxical outcome of the analysis is the finding that the number of workers in the 55+ age group in the labor market increased for both genders and across the country. The focus of economic policy should be to mitigate the negative effects of the corona crisis through measures aimed at creating jobs and increasing employment.
\end{abstract}

Keywords: COVID-19, Labour market, Men, Women, Gender

JEL Classification: E24, J01

\footnotetext{
${ }^{1}$ Ing. Jakub Harman, Ekonomická univerzita v Bratislave, Slovenská republika, e-mail: jakub.harman@euba.sk, ORCID ID: https://orcid.org/0000-0001-8622-8716
} 


\section{1 Úvod}

Pandémia koronavírusu zasiahla svet nečakane a vel'mi rýchlo. Trh práce je jedným z trhov, ktorý bol vážne postihnutý touto krízou. Mnoho reštriktívnych opatrení, ako napríklad uzavretie vysoko-infikovaných okresov, či povinné dodržiavanie rozostupov (Social distancing), malo negatívny vplyv na dopyt po statkoch či službách. Z daného vyplýva, že musel byt' zákonite zasiahnutý aj trh práce, ked’že ten je odvodený od dopytu po tovaroch a službách. Z tohto dôvodu sa vel'ké množstvo odbornej literatúry zaoberá problematikou dopadov koronakrízy na trh práce. V našom príspevku sa taktiež zameriavame na dopady koronakrízy na trh práce na Slovensku. Na jednotlivé indikátory trhu práce sa pozeráme cez rodové hl'adisko, teda ktoré pohlavie zasiahla koronakríza silnejšie, a taktiež rôzne vekové skupiny či dosiahnutú úroveň vzdelania. Existujú predpoklady a empíria, že ženské pohlavie je počas koronakrízy zasiahnuté viac ako mužské (Alon et al., 2020; Reichelt et al., 2021; Bowers, 2020; Zontag et al., 2020; Albanesi a Kim, 2021). Zatial' čo ženy sa zdajú byt' vírusom menej zasiahnuté a viac dodržiavajú zavedené opatrenia na zníženie šírenia nákazy, riskujú, že budú viac trpiet' ekonomickými následkami pandémie, pretože sú zranitel’nejšie na trhu práce a nesú väčšinu bremena domácich prác a starostlivosti o deti, ktoré sa počas výluky podstatne zvýšili (Profeta, 2020). Tento predpoklad overujeme v našom príspevku v podmienkach Slovenskej republiky.

\section{Prehl'ad literatúry}

Podl'a výskumu autoriek Kartseva a Kuznetsova (2020) má koronakríza rozsiahle následky na trh práce v Rusku. Podl'a ich zistení je každý druhý ruský pracovník v ohrození straty zamestnania. Najvyššiemu riziku straty práce a príjmu v dôsledku epidémie čelia mladí l’udia, pracovníci s nízkym vzdelaním ako aj obyvatelia $\mathrm{v}$ menších mestách.

Bowers (2020) pozorovala dopad koronakrízy na trh práce v Izraeli. Z jej zistení vyplýva, že koronakríza viac zasiahla ženy naprieč všetkým vekovým kategóriám. Najviac zasiahnuté boli ženy židovského pôvodu a slobodné matky. Zatváranie škôl a škôlok bolo faktorom, ktorý spôsobil väčšiu stratu zamestnania u žien, pretože domácnosti si museli zvolit', koho príjmy je z ekonomického hl'adiska prijatel'nejšie stratit' a kto bude niest' primárnu zodpovednost' za starostlivost' o deti doma. 
V afrických krajinách boli taktiež postihnuté koronakrízou viac ženy ako muži (Copley et al., 2020). Konkrétne firmy vlastnené ženami boli viac postihnuté v porovnaní s firmami vlastnenými mužmi (približne o $9 \%$ firiem). Tento jav je spôsobený taktiež tým, že africké krajiny svoju ekonomiku sústred’ujú najmä v agropriemysle. Podl'a O'Sullivan et al. (2014) majú ženy pracujúce v agropriemysle nižší prístup k produktívnym vstupom, informáciám a likvidite ako muži - takže v čase krízy bude produktivita ich farmy a potravinová sebestačnost' najviac zasiahnutá.

Adams-Prassl et al. (2020) skúmali dopad koronakrízy na trh práce v krajinách USA a Vel'ká Británia. Ich zistenia naznačujú, že u žien a pracovníkov bez vysokoškolského vzdelania je výrazne väčšia pravdepodobnost' straty zamestnania, zatial' čo u mladších jednotlivcov je výrazne väčšia pravdepodobnost' poklesu zárobkov. Ich výsledky poukazujú na potrebu okamžitých politických opatrení zameraných na tie skupiny obyvatel'stva, ktoré sú krízou najviac postihnuté.

Bluedorn et al. (2021) nazvali recesiu spôsobenú koronakrízou ako „she-cession“, teda krízu ženského pohlavia. Ich zistenia v 38 krajinách poukazujú na to, že koronakríza výrazne viac zasiahla na trhu práce ženy ako mužov, a to najmä v sektoroch, ktoré sú typické pre ženy. Ich výskum navyše preukázal, že „,she-cession“ je iba krátkodobého charakteru, ked’že až dve tretiny sledovaných krajín v tret’om kvartáli roku 2020 nevykazovali recesiu.

López-Calva (2021) pozoruje dopady koronakrízy v krajinách Latinskej Ameriky a Karibiku. Podl'a odhadov môže koronakríza vrátit’ stav žien na trhu práce až o 10 rokov spät'. Jedným z dôvodov je fakt, že ženy majú v mnohých sektoroch, ktoré kríza negatívne zasiahla (obchod, vzdelávanie, cestovný ruch), vyššiu zapojenost’ pracovnej sily ako muži. Ďalším dôvodom je spôsob, akým tradičné rodové normy v tomto období nespravodlivo zat'ažujú ženy ešte väčším podielom neplatených domácich prác a opatrovatel'ských činností.

Monge-Naranjo a Sun (2021) porovnávajú indikátory trhu práce v podobe zamestnanosti žien a mužov na plný a skrátený úväzok počas finančnej krízy v rokoch 2008 - 2010 a koronakrízy začiatkom roku 2020. Ich zistenia odhalili, že v porovnaní s finančnou krízou sa zamestnanost' žien počas koronakrízy prepadla výraznejšie, a to najmä v prípade žien pracujúcich na skrátený úväzok. Autori to odôvodňujú tým, že recesia vyvolaná koronakrízou nie je „klasickou“ recesiou spôsobenou kolapsom finančného sektora či problémami v produkcii, tak ako sa to dialo v minulosti, ale politikami vlád a súkromného sektora za účelom boja proti šíreniu vírusu. 


\section{Dáta a metodológia}

Dáta využité v analýze boli zozbierané zo štatistických databáz Štatistického úradu Slovenskej republiky. Dáta pokrývajú roky 2019 a 2020 a sú zozbierané na úrovni 79 okresov a 8 krajov. Sledované indikátory trhu práce sú miera nezamestnanosti, počet disponibilných uchádzačov o pracovné miesto, miera ekonomickej aktivity a počet odpracovaných hodín. Počet pracujúcich na trhu práce sledujeme v kategóriách rozdelených podl'a vzdelania a veku. Premenné sú rozdelené podl'a pohlavia, aby bolo možné identifikovat' dopad na jednotlivé pohlavia. Náhl'ad na deskriptívnu štatistiku premenných poskytuje Tabul'ka 1 . V tabul'ke chýba premenná počet odpracovaných hodín, ked’že nebolo možné získat' dáta rozdelené podl'a pohlaví. Premennú ale považujeme za dôležitý indikátor trhu práce, a preto sme ju zaradili do analýzy.

Metodológia použitá $\mathrm{v}$ analýze sa zameriava na medziročné porovnanie stavu indikátorov trhu práce podl'a jednotlivých pohlaví. Ciel'om je identifikovat' dopady koronakrízy na sledované indikátory a zistit', ktoré pohlavie bolo na trhu práce viac postihnuté. Analýza vychádza z predpokladu, že ženské pohlavie bolo postihnuté krízou výraznejšie ako mužské, ked’že podobný scenár je možné pozorovat' aj v krízach v minulosti v rôznych krajinách po celom svete. Podobnú metodológiu používajú aj autori Landivar et al. (2020). 
Tabul'ka č. 1: Deskriptívna štatistika

\begin{tabular}{|c|c|c|c|c|c|c|}
\hline & \multicolumn{3}{|c|}{ Muži } & \multicolumn{3}{c|}{ Ženy } \\
\hline Premenná & $\mathbf{2 0 1 9}$ & $\mathbf{2 0 2 0}$ & Rozdiel & $\mathbf{2 0 1 9}$ & $\mathbf{2 0 2 0}$ & Rozdiel \\
\hline Nezamestnanost' & 4,47 & 7,28 & 2,81 & 6,49 & 9,11 & 2,619 \\
\hline Disponibilní uchádzači & 775,47 & 1263,25 & 487,79 & 939,94 & 1359,33 & 419,39 \\
\hline Miera ekonomickej aktivity & 67,78 & 66,80 & $-0,98$ & 52,54 & 51,99 & $-0,55$ \\
\hline Pracujúci podl'a vzdelania & & & & & & \\
\hline Bez vzdelania & 7,36 & 6,09 & $-1,28$ & 5,97 & 4,80 & $-1,12$ \\
\hline Nižšie stredné & 48,69 & 46,35 & $-2,34$ & 27,10 & 24,61 & $-2,49$ \\
\hline Úplné stredné & 80,17 & 80,50 & 0,33 & 65,58 & 64,41 & $-1,17$ \\
\hline Vysokoškolské & 40,95 & 40,42 & $-0,53$ & 47,15 & 49,21 & 2,06 \\
\hline Pracujúci podl'a veku & & & & & & \\
\hline $15-24$ & 11,48 & 10,14 & $-1,34$ & 6,15 & 5,59 & $-0,56$ \\
\hline $25-34$ & 44,95 & 43,39 & $-1,56$ & 30,80 & 29,41 & $-1,39$ \\
\hline $35-44$ & 51,38 & 50,19 & $-1,19$ & 42,41 & 41,05 & $-1,36$ \\
\hline $45-54$ & 40,39 & 40,21 & $-0,18$ & 39,00 & 39,05 & 0,05 \\
\hline $55+$ & 28,96 & 29,45 & 0,49 & 27,44 & 27,95 & 0,51 \\
\hline
\end{tabular}

Zdroj: ŠÚ SR (n.d.), vlastné výpočty

Pozn.: V tabul'ke sú uvedené priemery.

\section{Výsledky}

Kapitola Výsledky sa venuje vizuálnej interpretácii efektov koronakrízy na vybrané indikátory trhu práce v Slovenskej republike s ohl'adom na pohlavie. Graf 1 zobrazuje medziročnú zmenu miery nezamestnanosti podl'a pohlavia v jednotlivých okresoch Slovenskej republiky. Y-os zobrazuje medziročnú zmenu pre mužov a X-os pre ženy. Stredová čiara (uhlopriečka) naznačuje rovnakú zmenu pre obe pohlavia, a teda zachovanie úrovne rodovej rovnosti z predkrízového roku 2019. V prípade, že sa hodnota pozorovania nachádza nad stredovou čiarou, znamená to, že efekt je vyšší na strane mužov, a opačne, ak je hodnota pod ňou, viac boli postihnuté ženy. Prvou zaujímavost'ou grafu je, že všetky pozorovania majú kladnú hodnotu, čo znamená, že nezamestnanost' na celom Slovensku vplyvom koronakrízy rástla. Viac boli zasiahnutí muži (54\% okresov nad čiarou) ako ženy (46 \% okresov pod čiarou). Priemerný nárast nezamestnanosti mužov na Slovensku predstavoval 2,81 p.b., v prípade žien iba 2,62 p.b. Suverénne najhorším okresom je Sabinov, kde sa zvýšila nezamestnanost' o takmer 6 percentuálnych bodov v prípade oboch pohlaví. 
Všeobecne bolo východné Slovensko výraznejšie postihnuté v tomto ukazovateli - nárast mužov v priemere o 3,45 p.b. a žien o 2,67 p.b. - ako zvyšok Slovenska (západ 2,00 resp. 2,47 p.b. a stred 3,22 resp. 2,76 p.b.).

Graf č. 1: Miera nezamestnanosti podl'a pohlavia a okresov, medziročná zmena 2020/2019, p.b.

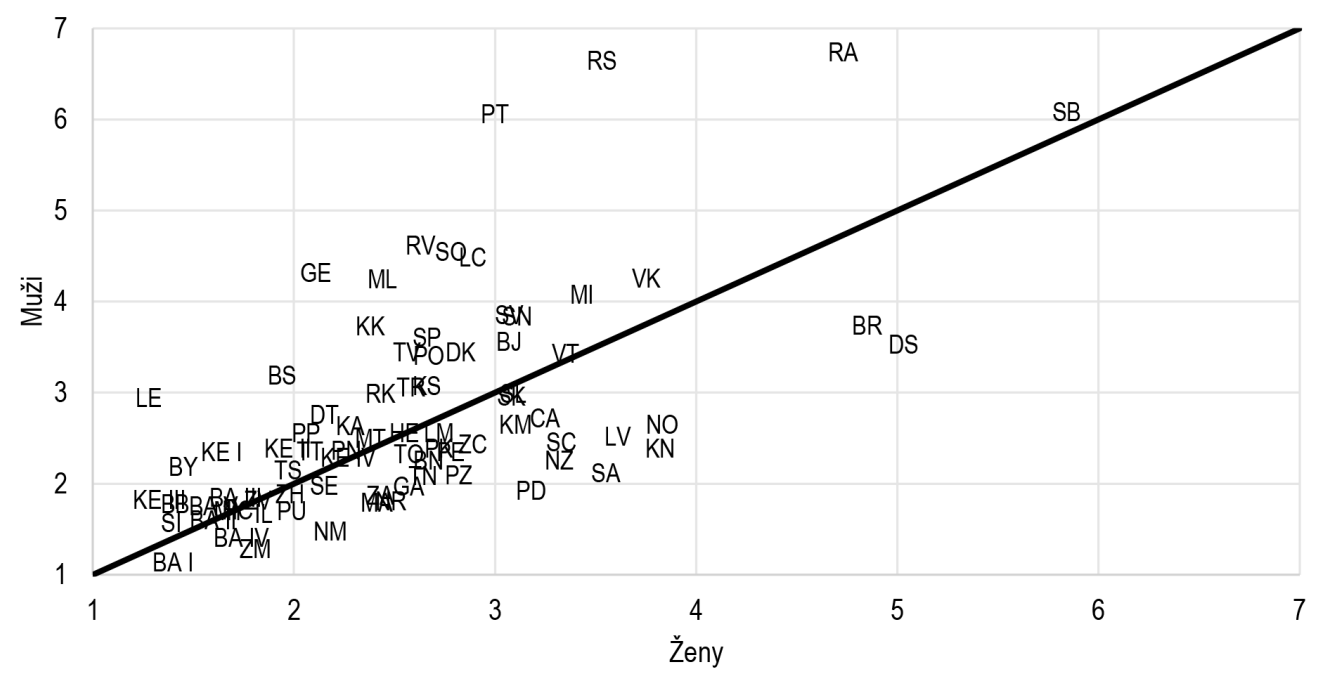

Zdroj: ŠÚ SR (n.d.), vlastné výpočty

Graf 2 poskytuje pohl'ad na indikátor disponibilného počtu uchádzačov o zamestnanie. Metodika je podobná ako v prípade predchádzajúceho ukazovatel'a. Illés a Ódor (2005) definuje disponibilného uchádzača o zamestnanie ako takého človeka, ktorý je schopný bezprostredne po predložení ponuky vol’ného pracovného miesta nastúpit' do zamestnania. Koronakríza v tomto ohl'ade opät' viac postihla mužov, a to vo všetkých okresoch Slovenska s výnimkou Komárna. V priemere sa zvýšil počet disponibilných uchádzačov o zamestnanie až o $62 \%$, pričom mužov až o $72 \%$, žien o $51 \%$. Celkovo pribudlo na trhu práce takmer 72000 disponibilných uchádzačov o zamestnanie. Pozoruhodným je dopad na okres Šal'a, kde sa hodnoty zvýšili o 146,86 \% u mužov (z 207 na 511 uchádzačov) a 116,71 \% u žien (z 353 na 765 uchádzačiek).

Počet odpracovaných hodín na zamestnanca patrí k základným ukazovatel’om trhu práce. Graf 3 zobrazuje práve tento ukazovatel' na úrovni okresov. Pre nedostupnost' dát nebolo možné analyzovat' tento ukazovatel' podl'a pohlaví, a preto sú na osiach porovnané priemerné hodnoty tohto ukazovatel'a pre 
roky 2020 (Y-os) a 2019 (X-os). V roku 2019 bolo v priemere odpracovaných 1648 hodín na zamestnanca, zatial' čo v roku 2020 to bolo iba 1575 . V roku 2020 teda bolo v priemere odpracovaných na jedného zamestnanca až o 73 hodín menej, čo predstavuje takmer dva celé pracovné týždne. Najvýraznejší dopad mala koronakríza v okrese Kysucké Nové Mesto, kde bolo v priemere na jedného zamestnanca odpracovaných až o 179 hodín menej ako v roku 2019. Podobne na tom boli aj Bánovce nad Bebravou s rozdielom 172 hodín. Tento rozdiel nie je možné pripísat' zmene v dňoch, ked' boli sviatky, ked’že počet sviatkov v pracovné dni bol v roku 2019 na hodnote 11 a o rok neskôr na hodnote 12 .

Graf č. 2: Disponibilný počet uchádzačov podl'a pohlavia a okresov, Index $2019=100$

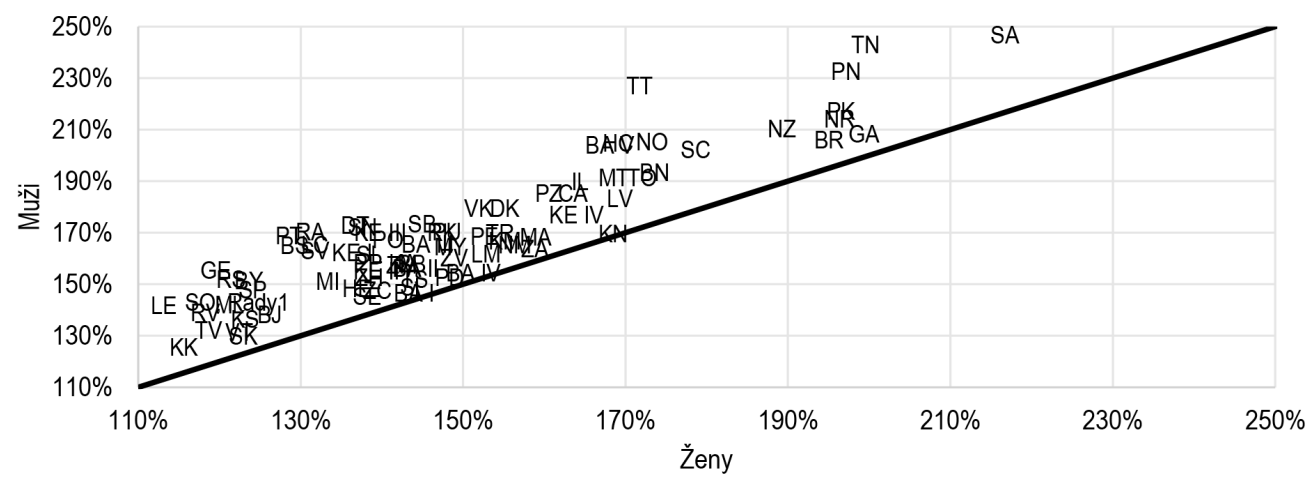

Zdroj: ŠÚ SR (n.d.), vlastné výpočty

Graf č. 3: Počet odpracovaných hodín na zamestnanca podl’a okresov

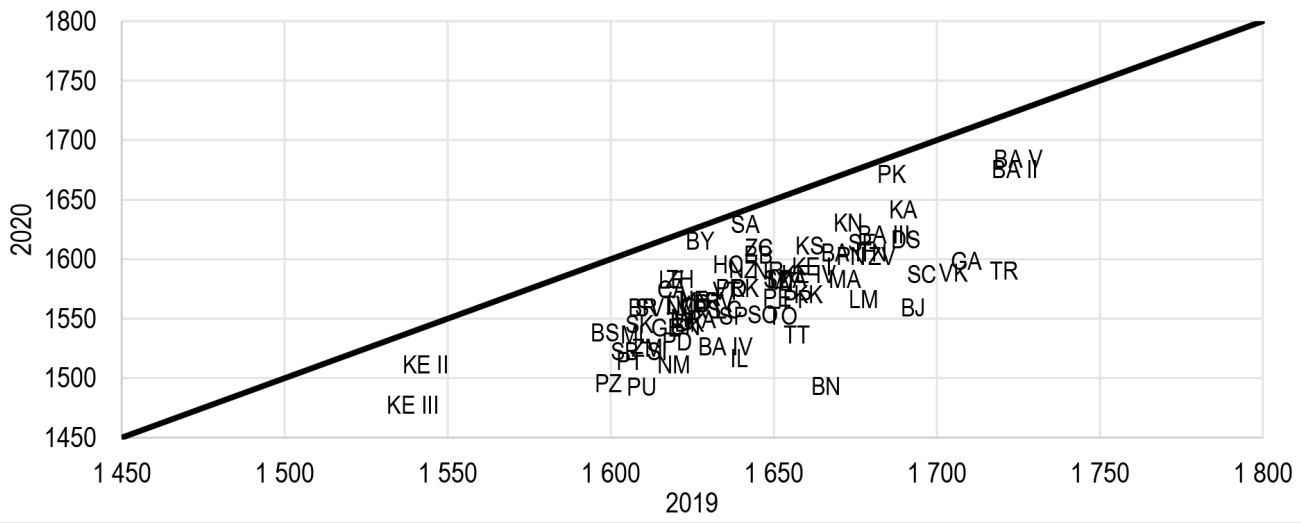

Zdroj: ŠÚ SR (n.d.), vlastné výpočty 
Miera ekonomickej aktivity je podl'a ŠÚ SR (2021) v percentách vyjadrený podiel ekonomicky aktívneho obyvatel'stva z obyvatel'stva vo veku od 15 do 89 rokov. Graf 4 zobrazuje medziročnú zmenu uvedeného ukazovatel'a. Kvôli obmedzenej dostupnosti dát sú prezentované výsledky podl'a pohlavia iba na úrovni krajov. Priemerná miera ekonomickej aktivity mužov na Slovensku predstavovala $67,78 \%$ v roku 2019 , resp. $66,80 \%$ v 2020 . V prípade žien to bolo 52,54 \%, resp. 51,99\% v roku 2020. Pri pohl'ade na graf vidíme, že až v 6 z 8 krajov došlo k poklesu ekonomickej aktivity mužov a v 5 krajoch u žien. V Košickom kraji bol výrazný pokles mužskej ekonomickej aktivity, a to až o takmer 4 p.b., zatial' čo ženy boli na predkrízových číslach. Banskobystrický kraj ako jediný zaznamenal nárast pri oboch pohlaviach. Môžeme konštatovat', že aj v tomto indikátore trhu práce si viac pohoršili muži ako ženy.

Graf č. 4: Miera ekonomickej aktivity podl'a pohlavia a krajov, medziročná zmena v p.b.

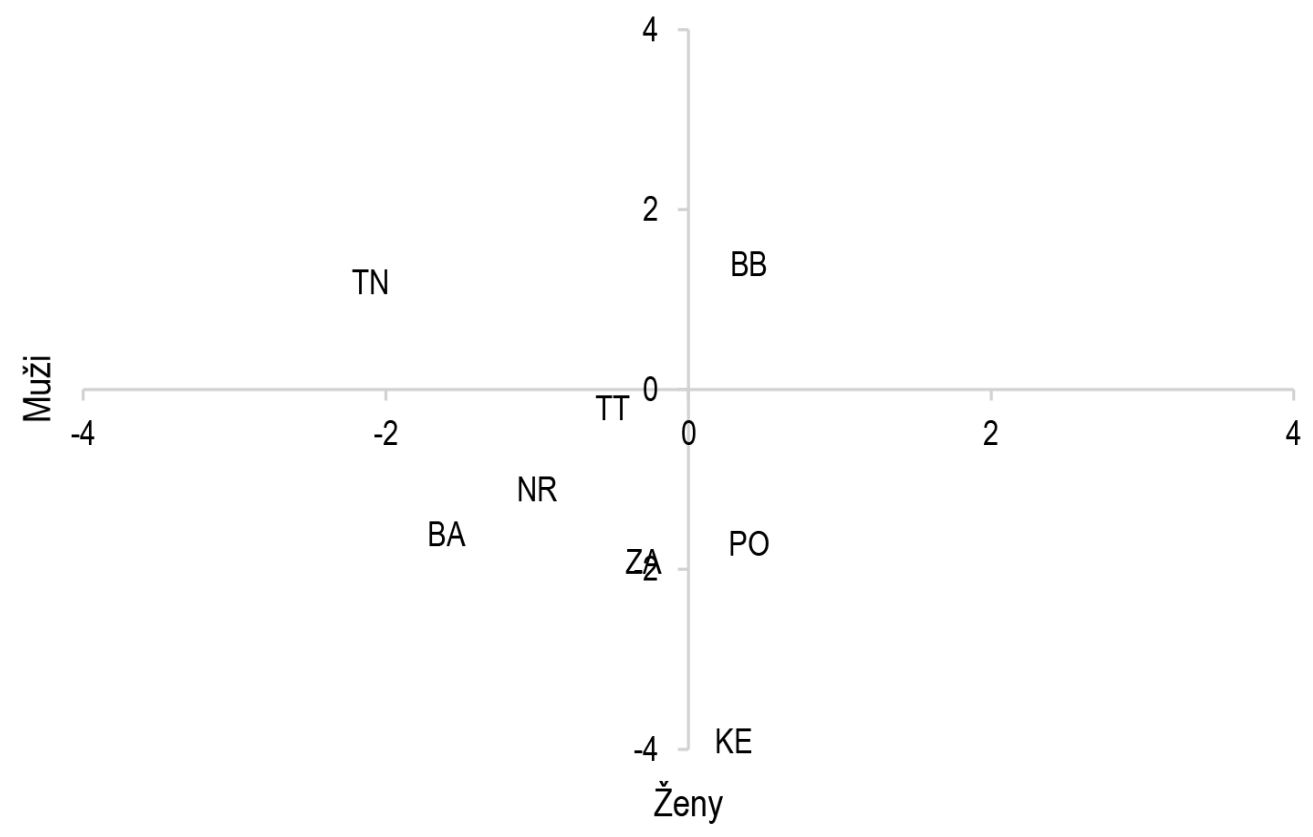

Zdroj: ŠÚ SR (n.d.), vlastné výpočty

Pracujúcich definuje ŠÚ SR (2021) ako všetky osoby v produktívnom a poproduktívnom veku, ktoré vykonávajú aspoň jednu hodinu akúkol'vek prácu za mzdu, plat, odmenu alebo pracovnú činnost' za účelom dosiahnutia zisku či nepracujúci z dôvodu choroby, dovolenky, náhradného vol’na, materskej alebo rodičovskej dovolenky, školenia či štrajku. Patria sem aj členovia rodiny, 
ktorí nepoberajú mzdu. Nasledujúci graf (5) zobrazuje rozdelenie pracujúcich podl'a pohlavia a vzdelania. Pri základnom (Graf 5a) a nižšom strednom vzdelaní (Graf 5b) predpokladáme, že viac budú postihnutí muži ako ženy, pretože práve muži pracujúci v typicky mužských odvetviach, ako napríklad stavebníctvo, majú počas kríz väčšiu tendenciu k prepusteniu. V prípade pracujúcich so základným vzdelaním a bez vzdelania sa tento predpoklad potvrdil (Graf 5a) iba v 3 krajoch. Rovnako v 3 krajoch utrpeli viac ženy a v 2 krajoch boli postihnuté obe pohlavia rovnako. V Košickom kraji bol dopad koronakrízy najväčší, ked’že o prácu prišlo až takmer 6100 pracujúcich s nízkym vzdelaním (3 200 mužov a 2900 žien). Zaujímavým zistením je, že v prípade nižšieho stredného vzdelania (Graf 5b) nebol dopad koronakrízy tak závažný. V dvoch krajoch (TT a BA) sa počet pracujúcich mužov oproti roku 2019 zvýšil. Počet pracujúcich žien sa však na celom Slovensku znižoval. Aj na tejto úrovni vzdelania bol najviac postihnutý pracovný trh v Košickom kraji, kde o prácu prišlo vyše 12000 l'udí, z čoho až 9400 boli muži.

Graf č. 5: Pracujúci podl'a pohlavia a vzdelania, Index $2019=100$

a) Základné a bez vzdelania

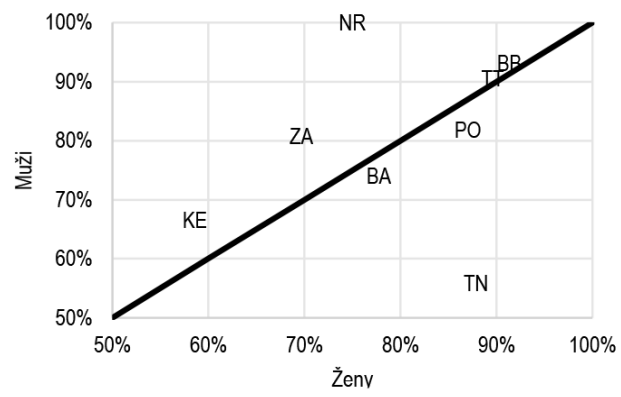

c) Úplné stredné vzdelanie

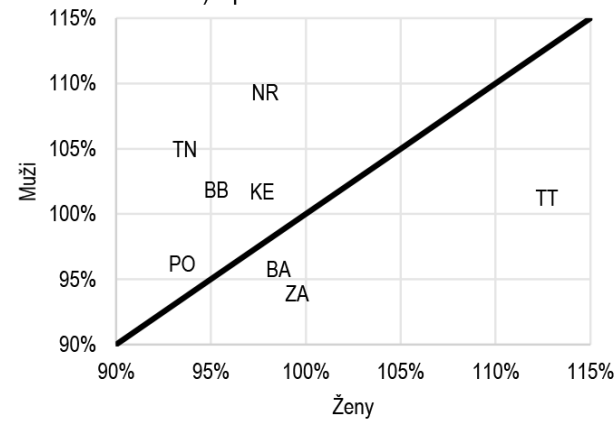

b) Nižšie stredné vzdelanie

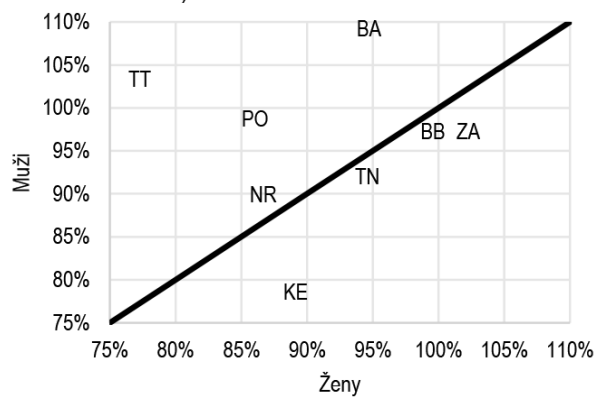

d) Vysokoškolské vzdelanie

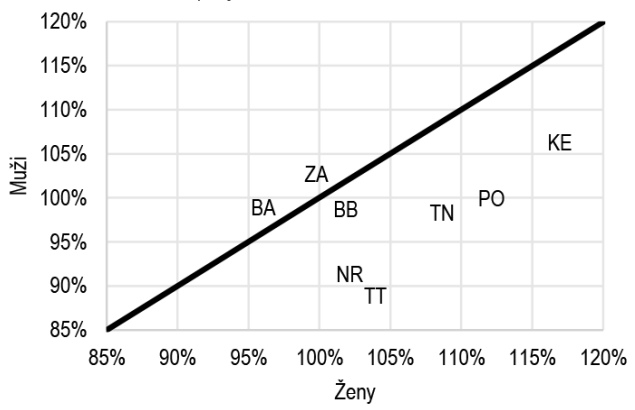

Zdroj: ŠÚ SR (n.d.), vlastné výpočty

Pozn.: Ak sa hodnota nachádza nad diagonálnou lineárnou priamkou, znamená to, že dopad krízy bol väčší u žien a naopak ak pod priamkou, tak u mužov. Hodnota ležiaca na priamke znamená rovnaký dopad na obe pohlavia. 
Grafy naznačujú, že čím vyššie vzdelanie pracujúcich, tým menší dopad koronakrízy na trh práce. Tento predpoklad potvrdzujú najmä grafy zobrazujúce úplné stredné (Graf 5c) a vysokoškolské vzdelanie (Graf 5d), kde sa väčšina hodnôt nachádza nad hranicou 100 \%. Tá indikuje predkrízovú úroveň počtu pracujúcich z roku 2019. Počet pracujúcich mužov s úplným stredným vzdelaním, teda maturitou, sa medziročne zvýšil až v 5 z 8 krajov. V Nitrianskom kraji až o takmer $10 \%$ (7 500 pracujúcich). V prípade žien s maturitou pozorujeme pokles vo všetkých krajoch s výnimkou Trnavského, kde sa ich počet zvýšil až o takmer $13 \%$, čo predstavuje nárast o približne 6900 pracujúcich žien. Na úrovni úplného stredného vzdelania boli viac postihnuté koronakrízou ženy. Opačná situácia nastala $\mathrm{v}$ prípade pracujúcich s vysokoškolským vzdelaním. Takmer na celom Slovensku došlo v prípade žien k rastu počtu pracujúcich. V Košickom kraji sa ich počet zvýšil až o takmer 17 \%, v Prešovskom o $12 \%$. Situácia sa pre mužov výrazne nezmenila. Ich počet sa v priemere znížil o necelé $2 \%$ (o prácu prišlo približne 4200 l’udí). Tento priemer čiastočne skresl'uje Trnavský a Nitriansky kraj, kde o prácu prišlo dokopy 6 400 l'udí, a Košický kraj, kde sa naopak zamestnalo dodatočných 3000 l'udí.

Z hl'adiska vývoja situácie na trhu práce je potrebné analyzovat' počet pracujúcich aj podl'a jednotlivých vekových kategórii. Graf 6 poskytuje pohl'ad na toto rozdelenie v Slovenskej republike. Koronakríza zasiahla mladých mužov výraznejšie ako mladé ženy najmä vo vekovej kategórii 15 - 24 rokov (Graf 6a). Iba Trnavský a Nitriansky kraj si dokázali udržat' počet pracujúcich na predkrízových hodnotách. V prípade Bratislavského kraja sa ich počet medziročne znížil o takmer 25 \%, naopak v Banskobystrickom kraji sa počet pracujúcich mladých žien zvýšil o takmer $10 \%$. Generácia 25 až 34-ročných (Graf 6b) bola koronakrízou zasiahnutá takmer minimálne. V tejto vekovej kategórii prišlo o prácu v priemere len približne $4 \%$ l'udí, pričom obe pohlavia boli postihnuté rovnakým dielom. Vyše 20000 l'udí vo veku 35 - 44 rokov (Graf $6 \mathrm{c}$ ) prišlo kvôli koronakríze o prácu, z toho takmer 11 tisíc žien a najmä v Banskobystrickom kraji, čo prehlbuje rodové nerovnosti na trhu práce. Žiaden z krajov Slovenska nevykazoval prírastok mužov v tejto vekovej kategórii. Opačná situácia nastala pri pohl'ade na vyššiu vekovú kategóriu 45 až 54-ročných (Graf 6d). Síce bola táto skupina zasiahnutá krízou iba minimálne, aj napriek tomu bolo prepustených viac mužov (1 400) ako žien, ktorých pri celoštátnom pohl'ade pribudlo približne 400 . V prípade najstaršej produktívnej kategórie (55+) pozorujeme prírastky v počte pracujúcich mužov v 5 krajoch a úbytok iba v dvoch (Graf 6e). V Košickom kraji sa ich počet 
takmer nezmenil. Množstvo žien pribudlo medziročne na trhu práce dokonca až v 6 krajoch. Celkový počet zamestnancov v tejto kategórii sa medziročne zvýšil až o 8000.

Graf č. 6: Pracujúci podl’a pohlavia a veku, Index $2019=100$

a) Vek $15-24$

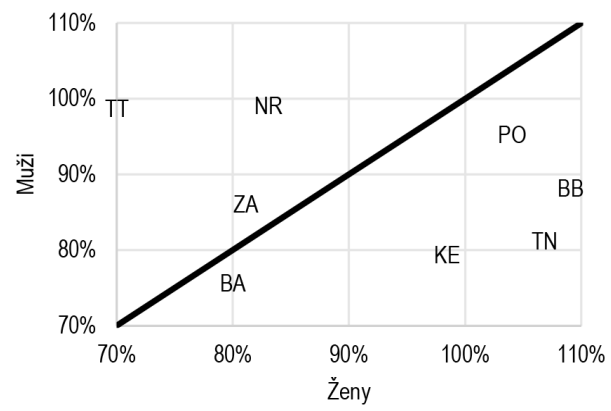

c) Vek $35-44$

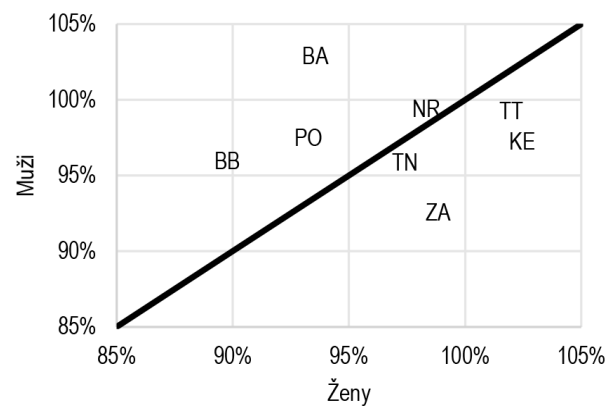

b) Vek $25-34$

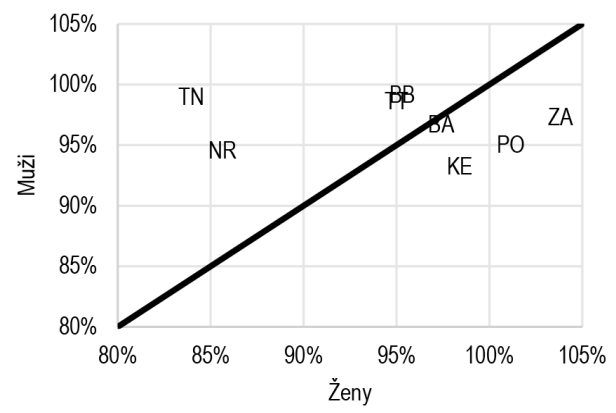

d) Vek $45-54$

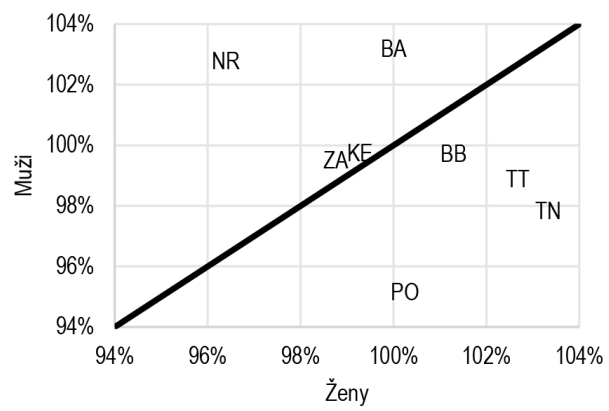

e) Vek 55+

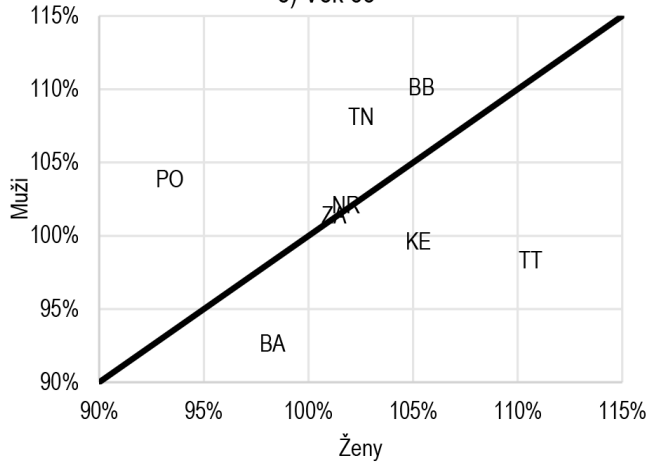

Zdroj: ŠÚ SR (n.d.), vlastné výpočty

Pozn.: Ak sa hodnota nachádza nad diagonálnou lineárnou priamkou, znamená to, že dopad krízy bol väčší u žien a naopak ak pod priamkou, tak u mužov. Hodnota ležiaca na priamke znamená rovnaký dopad na obe pohlavia. 


\section{Záver}

Ochorenie Covid-19 sa stalo hlavnou celosvetovou témou v priebehu posledných dvoch rokov. Negatívne dopady reštriktívnych opatrení na Slovensku, ale aj vo svete sú enormné. Príspevok sa zaoberá dopadom koronakrízy na trh práce v Slovenskej republike. Skúmaním vybraných indikátorov trhu práce na úrovni okresov a krajov identifikujeme vplyv koronakrízy na jednotlivé pohlavia podl'a veku a vzdelania. Z výsledkov vyplýva, že miera nezamestnanosti rástla na celom Slovensku, najmä na strednom a východnom, a zasiahla viac mužov ako ženy. Na ukazovatel' miery nezamestnanosti nadväzuje aj počet disponibilných uchádzačov o zamestnanie, ktorý taktiež rástol vo všetkých okresoch. Navyše vo všetkých okresoch boli postihnutí viac muži ako ženy. Ukazovatel' miery ekonomickej aktivity vykazuje podobné výsledky, ked'že sa priemerná zmena mužov pohybuje okolo -1 p.b., zatial' čo žien z trhu práce ubudlo len približne 0,5 p.b. Analýza počtu pracujúcich podl'a vzdelania preukázala, že existuje negatívny vzt’ah medzi úrovňou vzdelania a prepúšt’aním. Pracujúcich s nízkym vzdelaním ubudlo počas prvej a druhej vlny koronakrízy výrazne viac ako l'udí s vysokoškolským vzdelaním. Navyše sa ukázalo, že ženy s vyšším vzdelaním sú voči kríze odolnejšie. Výsledky taktiež preukázali, že mladé ženy zasiahla kríza menej ako mladých mužov. Najviac postihnutou vekovou kategóriou sú l'udia vo veku 35 - 44 rokov, kde bolo prepustených vyše 20 tisíc l'udí, z čoho až 11 tisíc boli ženy. Toto zistenie pripisujeme najmä tomu, že množstvo žien muselo zostat's det'mi doma počas karantény, ked'že výučba na školách prebiehala online formou $z$ domu. Podobne odvetvie cestovného ruchu a gastronómie, ktoré patrí medzi typicky ženské a pracujú v ňom najmä ženy tejto vekovej kategórie, počas koronakrízy výrazne utrpelo najmä kvôli tvrdému lockdownu. Ročníky od 45 do 54 rokov a viac neboli koronakrízou zasiahnuté v takej miere ako mladí l'udia. Ich počty sa na trhu práce výrazne nemenili, avšak zasiahnutí boli viac muži ako ženy. Paradoxne na koronakrízu najlepšie odpovedali l'udia vo veku 55+, ktorých počty sa na trhu práce medziročne zvýšili takmer na celom Slovensku.

Náš predpoklad o tom, že koronakríza zasiahne na trhu práce viac ženy ako mužov, sa nepotvrdil, ked’že z analýzy indikátorov trhu práce môžeme usúdit', že koronakríza viac zasiahla mužov ako ženy, a to najmä v prípade mužov s nízkym vzdelaním alebo vekom. Výsledky teda nepotvrdzujú rovnaký vplyv pandémie na Slovensku ako v iných krajinách sveta. Z hl'adiska rodovej rovnosti to síce môže znamenat' pozitívnu správu, pretože ukazovatele rodovej 
rovnosti budú naberat' pozitívne trendy, avšak zníženie rodovej nerovnosti na trhu práce nie je dosiahnuté ekonomicky prijatel'nou a želatel'nou cestou. Tá predstavuje zlepšovanie indikátorov trhu práce pre ženské pohlavie prostredníctvom dobiehania mužov, nie zhoršovaním indikátorov pre mužov. Hospodárska politika by sa podl'a nášho názoru mala zamerat' na opatrenia zvyšujúce zamestnanost' a vytváranie nových pracovných miest ako pre mužov, tak aj ženy, ked’že obe pohlavia boli koronakrízou významne zasiahnuté.

\section{Pod'akovanie}

Príspevok je výsledkom riešenia výskumného projektu VEGA č. 1/0037/20 „Nové výzvy a riešenia pre rast zamestnanosti v meniacich sa sociálno-ekonomických podmienkach“.

\section{LITERATÚRA}

[1] Adams-Prassl, A., Boneva, T., Golin, M., \& Rauh, C. (2020). Inequality in the impact of the coronavirus shock: Evidence from real time surveys. Journal of Public Economics, 189, 104245. https://doi.org/10.1016/j.jpubeco.2020.104245

[2] Albanesi, S., \& Kim, J. (2021). Effects of the COVID-19 Recession on the US Labor Market: Occupation, Family, and Gender. Journal of Economic Perspectives, 35(3), 3 - 24. https://doi.org/10.1257/jep.35.3.3

[3] Alon, T., Doepke, M., Olmstead-Rumsey, J., \& Tertilt, M. (2020). The impact of the coronavirus pandemic on gender equality. Covid Economics Vetted and Real-Time Papers, $4,62-85$.

[4] Bluedorn, J., Hansen, N.-J., Shibata, I., Caselli, F., \& Mendes Tavares, M. (2021). Gender and Employment in the COVID-19 Recession: Evidence on "She-cessions." IMF Working Papers, 2021(095), 1. https://doi.org/10.5089/9781513575926.001

[5] Bowers, L. (2020). The coronavirus crisis and women in the labor market: permanent damage or short-term setback with long-term potential. Viral Economics, Taub Center.

[6] Copley, A., Decker, A., Delavelle, F., Goldstein, M., O’Sullivan, M., \& Papineni, S. (2020). COVID-19 Pandemic Through a Gender Lens. World Bank. https://doi.org/10.1596/34016

[7] Illés, Z., \& Ódor, L. (2005). Analýza základných indikátorov trhu práce v SR. Inštitút finančnej politiky Ministerstva financií SR, Bratislava. 
[8] Kartseva, M. A., \& Kuznetsova, P. O. (2020). The economic consequences of the coronavirus pandemic: which groups will suffer more in terms of loss of employment and income? Population and Economics, 4(2), $26-33$.

https://doi.org/10.3897/popecon.4.e53194

[9] Landivar, L. C., Ruppanner, L., Scarborough, W. J., \& Collins, C. (2020). Early Signs Indicate That COVID-19 Is Exacerbating Gender Inequality in the Labor Force. Socius: Sociological Research for a Dynamic World, 6.

https://doi.org/10.1177/2378023120947997

[10] López-Calva, L. F. (2021). The Gender Penalties of the Pandemic: The disproportionate impact of COVID-19 on women's labor market outcomes. UNDP Latin America and Caribbean.

[11] Reichelt, M., Makovi, K., \& Sargsyan, A. (2020). The impact of COVID-19 on gender inequality in the labor market and gender-role attitudes. European Societies, 23(1), 228 - 245. https://doi.org/10.1080/14616696.2020.1823010

[12] Monge-Naranjo, A., \& Sun, Q. (2021). Women Affected Most by COVID-19 Disruptions in the Labor Market. The Regional Economist, 29(1)

[13] O'Sullivan, M. et al. (2014). Levelling the field: improving opportunities for women farmers in Africa. World Bank Group. Washington DC

[14] Profeta, P. (2020). Gender Equality and Public Policy during COVID-19. CESifo Economic Studies, 66(4), 365 - 375. https://doi.org/10.1093/cesifo/ifaa018

[15] Zontag, N., Epstein, G., \& Weiss, A. (2020). The Israeli Labor Market Under the Coronavirus: An Overview. State of the nation report: Society, economy and policy in Israel.

[16] ŠÚ SR. (2021). Práca. Dostupné na: https://slovak.statistics.sk:443/wps/portal?urile=wcm:path:/obsah-sk/static-content/temy/demografia-a-socialna-statistika/praca/ metaudaje

[17] ŠÚ SR. (n.d.). Databáza DATACUBE. Dostupné na: http://datacube.statistics.sk/ 